\title{
PIAS1 wt Allele
}

National Cancer Institute

\section{Source}

National Cancer Institute. PIAS1 wt Allele. NCI Thesaurus. Code C104796.

Human PIAS1 wild-type allele is located in the vicinity of $15 q 23$ and is approximately 137 $\mathrm{kb}$ in length. This allele, which encodes E3 SUMO-protein ligase PIAS1 protein, plays a role in both protein sumoylation and signaling. 